Note

\title{
Hydro-physical characterization of soils under tropical semi-deciduous forest
}

\author{
Miguel Cooper ${ }^{1 *}$, Jaqueline Dalla Rosa², João Carlos Medeiros², Thalita Campos de Oliveira², Raul Shiso Toma², Carlos Eduardo \\ Pinto Juhász $2, \S$
}

IUSP/ESALQ - Depto. de Ciência do Solo, C.P. 09 - 13418-900 - Piracicaba, SP - Brasil. 2USP/ESALQ - Programa de Pós Graduação em Solos e Nutrição de Plantas.

${ }^{*}$ Corresponding author <mcooper@esalq.usp.br>

Edited by: José Miguel Reichert

Received April 20, 2010

Accepted October 10, 2011

\begin{abstract}
The study of the hydro-physical behavior in soils using toposequences is of great importance for better understanding the soil, water and vegetation relationships. This study aims to assess the hydro-physical and morphological characterization of soil from a toposequence in Galia, state of São Paulo, Brazil). The plot covers an area of 10.24 ha $(320 \times 320$ m), located in a semi-deciduous seasonal forest. Based on ultra-detailed soil and topographic maps of the area, a representative transect from the soil in the plot was chosen. Five profiles were opened for the morphological description of the soil horizons, and hydro-physical and micromorphological analyses were performed to characterize the soil. Arenic Haplustult, Arenic Haplustalf and Aquertic Haplustalf were the soil types observed in the plot. The superficial horizons had lower density and greater hydraulic conductivity, porosity and water retention in lower tensions than the deeper horizons. In the sub-superficial horizons, greater water retention at higher tensions and lower hydraulic conductivity were observed, due to structure type and greater clay content. The differences observed in the water retention curves between the sandy $E$ and the clay B horizons were mainly due to the size distribution, shape and type of soil pores.

Keywords: Ultisol, Alfisol, water retention, soil functioning, image analysis
\end{abstract}

\section{Introduction}

The understanding about how soil influences the native vegetation, and vice versa, is fundamental for the definition and characterization of the mechanisms that influence the development and distribution of species inside a native forest, as well as the determination of their resilience and sustainability. There is a close relationship between local edaphic characteristics and the richness, distribution and variety of forest species (Tersteege et al., 1993; Sabatier et al., 1997; Clark et al., 1999; Gomes et al., 2004). The study of soil functioning and behavior associated to the soil-vegetation studies provides a broader panorama of how the natural soil dynamics interferes on vegetation.

The inclusion of soil hydrodynamic data in studies of the soil-plant relationships has been suggested by Ruggiero et al. (2002) and used by Oliveira et al. (2005) and Quesada et al. (2004). Soil depth, texture and organic matter content affect water retention in soil (Wall and Heiskanen, 2003). Generally, in the more superficial soil layer, the total porosity is greater and more water is retained in the lower tension points of the soil retention curves, decreasing as it moves down in the profile, information necessary to estimate the water's movement through the soil profile (Chertkov, 2004).

The soil-forest dynamics studied through water movement along the soil profile is fundamental, because the availability of water in the soil is one of the most important factors for plant growth (Guehl, 1984). Micromorphological techniques through image analysis could provide useful information about the soil pore system

§In memorian.
(Castro et al., 2003) and, associated with the soil hydric behavior, help in understanding the soil vs water vs. vegetation relationship. In this way, it is possible to know the relationships established inside the soil system and how they are involved in and influence the landscape.

The aim of this study is to characterize the soil morphology and hydro-physical behavior of a toposequence, in the Caetetus Ecological Station (Galia, SP, Brasil), assuming that the hydro-physical behavior of the soil is a possible factor that defines the local vegetation type.

\section{Materials and Methods}

The study was carried in Gália and Alvinlândia, State of São Paulo, Brazil, between the geographic coordinates of $22^{\circ} 41^{\prime}, 22^{\circ} 46^{\prime} \mathrm{S}$ and $49^{\circ} 10^{\prime}, 49^{\circ} 16^{\prime} \mathrm{W}$ and altitudes ranging from 500 and $680 \mathrm{~m}$, in a tropical semideciduous mesophytic forest. The climate is classified as Cwa, according to the Köppen classification (1948). The predominant geological formation is sandstone, from Marília and Adamantina formations of the Bauru group. Secondarily, undifferentiated continental and alluvial sediments are found in the region.

The plot size was 10.24 ha and was subdivided into 256 sub-plots of $20 \times 20 \mathrm{~m}$, demarcated based on planialtimetric surveys. Using soil maps, a transect that covered the most representative soils of the area was selected. Profiles were opened to a depth of $1.5 \mathrm{~m}$ in the major soil classes found in this transect, where a soil morphological description was performed according to the methodology proposed by Lemos and Santos (2002). Details of the soil morphology in the chosen toposequence were obtained with an auger, using the method proposed by Boulet et al. (1982), known as structural 
analysis. To characterize the toposequences, topographic measurements of altitudes were performed each $5 \mathrm{~m}$. Intermediate points were drilled using an auger between the profiles up to $1.5 \mathrm{~m}$ depth, in order to delimit the vertical and lateral transitions between the different soil horizons described in the profiles.

Deformed soil samples were collected from the profiles opened and in each horizon using an auger to determine the following soil attributes: soil particle distribution according to the methodology proposed by Gee and Bauder (1986); particle density according to the methodology described by Vomocil (1965); and soil organic carbon (OC) through oxidation, reducing $\mathrm{Cr}$ (III) ions of potassium dichromate with readings using the colorimetric method (Quaggio and Van Raij, 2001).

Non-deformed soil samples were collected in three replicates per soil horizon in each profile opened to determine the soil bulk density (BD), porosity and water retention curves. The $\mathrm{BD}$ was determined according to the methodology proposed by Blake and Hartge (1986). The evaluated porosities comprised macro, micro and total porosity: soil macroporosity (Mac) was determined using a sand-filled chamber adjusted to $50 \mathrm{~cm}$ of tension (Topp and Zebchuk, 1979); total soil porosity (TP) was calculated using soil bulk density and particle density (PD) through the equation proposed by Vomocil (1965). The microporosity (Mic) was obtained by the difference between TP and Mac.

In order to obtain the soil water retention curves, undisturbed samples were saturated and submitted to tensions $(1,3,5,8$, and $10 \mathrm{kPa})$ using a sand-filled chamber (Topp and Zebchuk, 1979), and the tensions (33, 100, 500 , and $1,500 \mathrm{kPa}$ ) using a Richards chamber (Klute, 1986). After finishing the drainage in each tension, the water retained in the soil was quantified and the volumetric moisture was calculated. The adjustments for the soil water retention curves were performed by van Genuchten model (Van Genuchten, 1980), using SWRC software, version 2.00 (Dourado Neto et al., 2000).

The saturated hydraulic conductivity (Ks) in the field was obtained using the Guelph permeameter (Reynolds et al., 1983) in three of the five profiles opened for morphological characterization and soil sampling. Three replicates for each horizon were obtained. To calculate saturated hydraulic conductivity, the single hydraulic charge equation proposed by Elrick et al. (1989) was applied.

For image analysis, undisturbed soil cores were collected in each horizon described in the profiles. These samples were first air dried and subsequently dried in an oven at $40{ }^{\circ} \mathrm{C}$ until constant mass. Afterwards, samples were impregnated with a polyester resin (Murphy, 1986), styrene monomer (Castro et al., 2003), a catalyzer (Ringrose-Voase, 1991) and a fluorescent pigment (Murphy et al., 1977). To increase the impregnation efficiency and facilitate resin penetration in the soil, a vacuum system was used (Castro et al., 2003). Once hardened, the impregnated cores were cut and one of the faces was polished.
The area occupied by pores and the pore shape were obtained from the image analysis of each impregnated core, according to the two form indexes described by Cooper and Vidal-Torrado (2005). Pores were quantified from the images acquired on the polished faces of the impregnated cores. Fourteen random images (photomicrographs) were taken by a color digital camera. Pores were segregated by manual grayscale thresholds for each set of images and viewed in two dimensions. Once acquired, the image was binarized and the pores were individualized using Noesis ${ }^{\circledR}$ Visilog 5.4 image analysis software. The shape of the pores was classified as rounded, elongated and complex, and the size as small, medium and large.

\section{Results and Discussion}

The permanent plot of the Caetetus Ecological Station is occupied by a semi-deciduous mesophytic forest, which develops over Arenic Haplustults and Arenic Haplustalfs as well as Aquertic Haplustalfs. The Arenic Haplustults and Arenic Hapustalfs occur on hilly landscapes with altitudes ranging from 564 to $550 \mathrm{~m}$, and the Aquertic Haplustalfs are associated with a floodplain of a first-order channel which runs parallel to the northwesthern side of the permanent plot.

According to the American Soil Classification System (Soil Survey Staff, 2010) the soils of the profiles in the transect studied were classified as Arenic Haplustults (T1), Arenic Haplustalfs (T2), Arenic Haplustalfs (T3), Grossarenic Haplustalfs (T4), and Aquertic Haplustalfs (T5) (Figure 1 and Table 1).

The soils of the plot had lateral and vertical heterogeneity among horizons, where the texture and structure were the main attributes responsible for the heterogeneity. The transect had two very distinct compartments. One compartment occupies the summit, shoulder and backslope positions, where well-drained soils predominate (Arenic Haplustult and Arenic Haplustalf). Soils on this compartment are characterized by an abruptic textural gradient, showing poorly structured horizons with loamy sand to sandy texture up to depths of $1.0 \mathrm{~m}$. Directly below are well structured horizons with loamy clay texture. The second compartment occupies the toeslope (Grossarenic and Aquentic Haplustalfs), where the soils present drainage restrictions in the deeper horizons. These soils also have an abrupt textural gradient between the superficial and sub-superficial horizons (Figure 1 and Table 1). The distribution of soils along the slope and the horizon morphological attributes determine the hydro-physical functioning of the soils and the toposequence, as discussed below.

The BD of the Arenic Haplustults and Arenic Haplustalfs ranged from de 1.22 to $1.75 \mathrm{Mg} \mathrm{m}^{-3}$, and in the Grossarenic and Aquentic Haplustalfs from 0.92 to 1.63 $\mathrm{Mg} \mathrm{m}^{-3}$ (Table 2). As expected, an increase in the BD of the Bt horizon and a consequent decrease in the total porosity in relation to structural and textural changes 


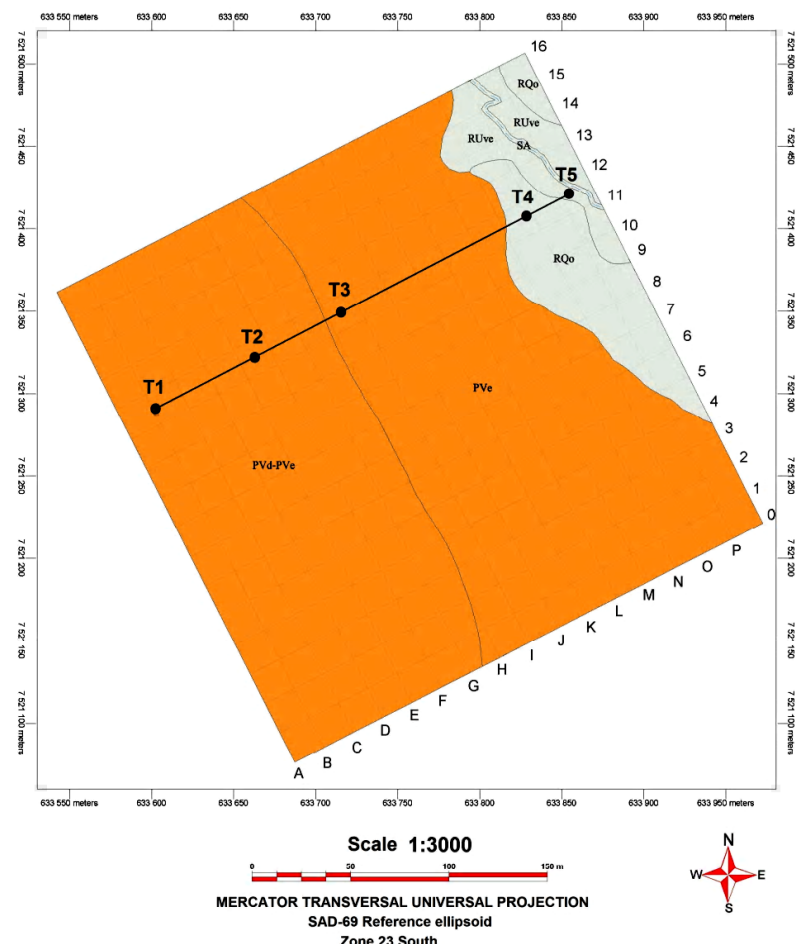
ULTRADETAILED SOIL MAP OF THE PERMANENT
PLOT LOCATED IN THE CAETETUS ECOLOGICAL STATION

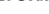

$\mathrm{T} 2$

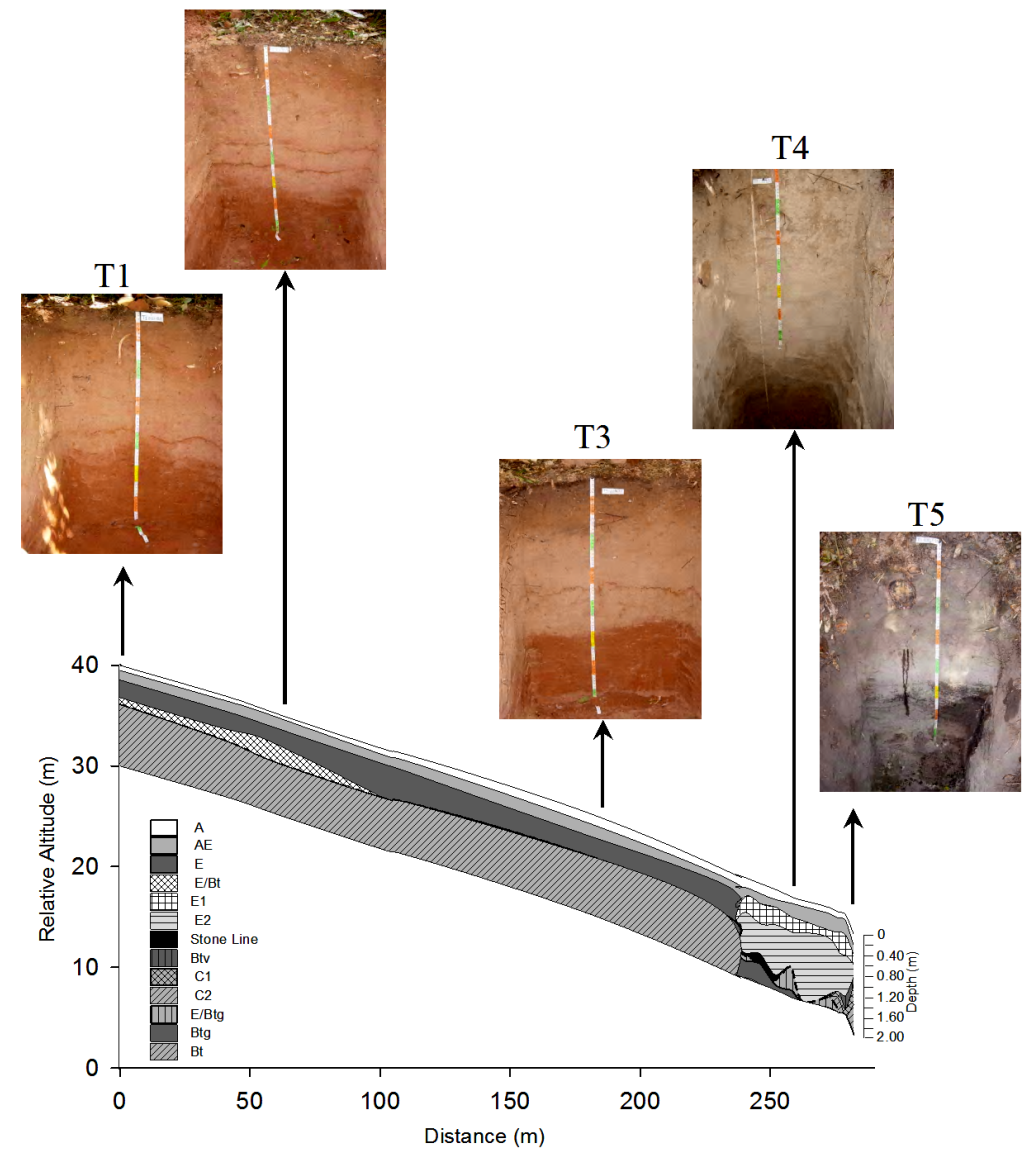

Figure 1 - Soils map of the permanent plot of the Caetetus Ecological Station (Gália - SP, Brazil), with localization of the transect and photography from each profile. 
Table 1 - Soil morphological description, for the studied profiles of the Caetetus Ecological Station (Gália, SP, Brazil).

\begin{tabular}{|c|c|c|c|}
\hline Horizon (Depth) & Structure & Texture & Color moist (Munsell) \\
\hline & & Profile 1 - Arenic Haplustults & \\
\hline$A(0.00-0.10)$ & MOD to WE BL SUB SM & Loamy & $5 Y R 3 / 3$ \\
\hline$A E(0.10-0.29)$ & WE BL SUB AVE SM & Sandy & $5 Y R \quad 4 / 4$ \\
\hline$E(0.29-0.64)$ & WE BL SUB AVE SM & Sandy & 5YR 5/4 \\
\hline EB $(0.64-0.78)$ & WE BL SUB AVE & Sandy & $5 Y R 4 / 4-2.5 Y R 4 / 6$ \\
\hline \multirow[t]{2}{*}{ Bt $(0.78-1.23+)$} & ST BL SUB AVE SM & Clay loam sandy & $2.5 Y R 4 / 4$ \\
\hline & & Profile 2 - Arenic Haplustalfs & \\
\hline$A(0.00-0.07)$ & WE BL SUB AVE SM & Sandy & $5 Y R 4 / 2$ \\
\hline$A E(0.07-0.29)$ & WE BL SUB SM & Sandy & $5 Y R 4 / 4$ \\
\hline$E(0.29-0.61)$ & WE BL SUB AVE SM & Sandy & 5YR 5/4 \\
\hline EB $(0.61-0.98)$ & MOD to WE BL SUB AVE & Sandy & $5 Y R \quad 4 / 6-2.5 Y R \quad 4 / 6$ \\
\hline \multirow[t]{2}{*}{ Bt $(0.98-1.35+)$} & ST BL SUB AVE & Loamy & $2.5 Y R 3 / 6$ \\
\hline & & Profile 3 - Arenic Haplustalfs & \\
\hline$A(0.00-0.13)$ & WE BL SUB PEQ and GRA & Sandy & $5 Y R 3 / 2$ \\
\hline $\mathrm{AE}(0.13-0.34)$ & MOD to WE BL SUB AVE & Sandy & $5 Y R 4 / 3$ \\
\hline$E(0.34-0.95)$ & WE to very WE BL SUB AVE & Sandy & 5YR 5/4 \\
\hline \multirow[t]{2}{*}{ Bt $(0.95-1.35+)$} & ST BL SUB AVE & Clay loam. sandy & $2.5 Y R 4 / 6$ \\
\hline & & Profile 4 - Grossarenic Haplustalfs & \\
\hline$A(0.00-0.13)$ & Very WE CRU & Sandy & 10YR 5/1 \\
\hline $\mathrm{AE}(0.13-0.40)$ & WE BL AVE & Sandy & $2.5 Y 6 / 2$ \\
\hline$E(0.40-1.40)$ & Extremely WE BL SUB AVE SM & Sandy & 10YR $7 / 1$ \\
\hline $\mathrm{EB}(1.40-1.86)$ & WE BL SUB AVE & Sandy & 10YR 7/2 - 10YR 6/6 \\
\hline \multirow[t]{2}{*}{ Btg $(1.86-2.50+)$} & MOD BL SUB AVE & Sandy & $5 Y$ 6/1 - 5YR 5/6 - 7.5YR 5/6 - 10YR 6/4 \\
\hline & & Profile 5 - Aquertic Haplustalfs & \\
\hline$A(0.00-0.22)$ & WE BL SUB PEQ and GRA & Loamy & 10YR 3/1 \\
\hline $\mathrm{AE}(0.22-0.53)$ & MOD to WE BL SUB AVE & Sandy & 10YR $3 / 2$ \\
\hline$E(0.53-0.86)$ & MOD to WE BL SUB AVE & Sandy & 10YR 5/1 \\
\hline $\mathrm{Bg}(0.86-1.00)$ & ST BL ANG & Clay Sandy & $2.5 Y 2 / 0$ \\
\hline$C(1.00-1.40+)$ & MOD to WE BL SUB AVE & Sandy & 10YR 5/1 \\
\hline
\end{tabular}

$\mathrm{MOD}=$ moderate; $\mathrm{WE}=$ weak; GRA = granular; $\mathrm{AVE}=$ Average; $\mathrm{BL}=$ blocks; $\mathrm{SUB}=$ subangular; $\mathrm{SM}=\mathrm{Small} ; \mathrm{ST}$ = strong; $\mathrm{CRU}=$ crumbs; $\mathrm{ANG}=$ angular.

in the morphological descriptions were observed. In the profiles with abruptic textural gradients, the differences of the density and porosity were more pronounced. The higher $\mathrm{BD}$ values observed in the $\mathrm{E}$ horizons were mainly related to the quartz dominance in the sand fraction, with no aggregation and lower TP. The low BD values observed in all superficial horizons were related to greater organic carbon content and TP (Godefroy and Joacquin, 1975; Araújo et al., 2004).

The PD had similar values in all of the toposequence, ranging from 2.38 to $2.70 \mathrm{Mg} \mathrm{m}^{-3}$ (Table 2), this occurred due to the similar constitution of the soil particles in these soils. The soil Mac ranged from 0.05 to $0.22 \mathrm{~m}^{3} \mathrm{~m}^{-3}$ in the Arenic Haplustults and Arenic Haplustalfs, and from 0.06 to $0.23 \mathrm{~m}^{3} \mathrm{~m}^{-3}$ in the Grossarenic and Aquentic Haplustalfs (Table 2), with greater values observed in the soil surface horizons. These values resulted from the better soil structure in the more superficial layers of this native forest, caused by the input of organic matter and greater biological activity. The same tendency occurred for the Mic, which varied from 0.44 to $0.24 \mathrm{~m}^{3} \mathrm{~m}^{-3}$ in the Arenic Haplustults and Arenic Haplustalfs and 0.42 to $0.27 \mathrm{~m}^{3} \mathrm{~m}^{-3}$ in the Grossarenic and Aquentic Haplustalfs. The TP was greater in the A horizon in all profiles, ranging from 0.65 to $0.44 \mathrm{~m}^{3} \mathrm{~m}^{-3}$. This was also related to a better organization of soil particles and to high levels of $\mathrm{OC}$, ranging from 37.2 to 11.2 $\mathrm{g} \mathrm{kg}^{-1}$ (Table 2).

The soil water retention curves of the profiles demonstrated the influence of the soil's textural and structural attributes. There was a clear differentiation between the sandy superficial horizons and the clayey sub-superficial horizons (Figure 2). In all of the profiles studied, the volumetric moisture determined in each of the measured tensions was greater in the B horizon (deepest horizon) when compared to the other horizons. This corroborated the findings of Wall and Heiskanen (2003), who stated that soil depth and texture, beyond organic matter content, affect significantly water retention. For each tension measured, the denser horizons retain greater volume of water than the other horizons analyzed, even when the soil was close to the permanent wilting point.

Moreover the water retention curves of the sandy horizons demonstrated good conduction proprieties, which was evidenced by the high moisture volume in the lowest potentials, it retained very little water in tensions closer to the permanent wilting point $(1500 \mathrm{kPa})$. 
Table 2 - Soils physical attributes for the studied profiles of the Caetetus Ecological Station (Gália, SP, Brazil).

\begin{tabular}{|c|c|c|c|c|c|c|c|c|c|}
\hline \multirow[t]{3}{*}{$\begin{array}{l}\text { Horizon } \\
\text { depth - cm }\end{array}$} & Clay & Silt & Sand & PD & $\mathrm{BD}$ & $\mathrm{OC}$ & Mac & Mic & TP \\
\hline & \multirow{2}{*}{\multicolumn{3}{|c|}{$\mathrm{g} \mathrm{kg}^{-1} \longrightarrow$}} & \multicolumn{2}{|c|}{$-\mathrm{Mg} \mathrm{m}^{-3}-$} & $\mathrm{g} \mathrm{kg}^{-1}$ & \multicolumn{3}{|c|}{$\mathrm{m}^{3} \mathrm{~m}^{-3}$} \\
\hline & & & & & Arenic & cults & & & \\
\hline$A(0.00-0.10)$ & 140 & 40 & 820 & 2.67 & 1.26 & 31.6 & 0.15 & 0.38 & 0.53 \\
\hline$A E(0.10-0.29)$ & 100 & 40 & 860 & 2.74 & 1.46 & 13.0 & 0.10 & 0.37 & 0.46 \\
\hline$E(0.29-0.64)$ & 100 & 20 & 880 & 2.60 & 1.51 & 10.2 & 0.10 & 0.32 & 0.42 \\
\hline EB $(0.64-0.78)$ & 100 & 40 & 860 & 2.74 & 1.47 & 9.3 & 0.11 & 0.35 & 0.46 \\
\hline \multirow[t]{2}{*}{$\mathrm{Bt}(0.78-1.23+)$} & 240 & 40 & 720 & 2.63 & 1.38 & 11.2 & 0.13 & 0.34 & 0.47 \\
\hline & \multicolumn{9}{|c|}{ Profile 2 - Arenic Haplustalfs } \\
\hline$A(0.00-0.07)$ & 120 & 20 & 860 & 2.53 & 1.34 & 37.2 & 0.22 & 0.26 & 0.47 \\
\hline AE $(0.07-0.29)$ & 120 & 40 & 840 & 2.56 & 1.46 & 14.9 & 0.17 & 0.26 & 0.43 \\
\hline$E(0.29-0.61)$ & 100 & 40 & 860 & 2.67 & 1.51 & 11.2 & 0.14 & 0.30 & 0.43 \\
\hline EB $(0.61-0.98)$ & 100 & 40 & 860 & 2.53 & 1.52 & 9.3 & 0.09 & 0.31 & 0.40 \\
\hline \multirow[t]{2}{*}{ Bt $(0.98-1.35+)$} & 180 & 20 & 800 & 2.67 & 1.54 & 9.3 & 0.10 & 0.33 & 0.42 \\
\hline & \multicolumn{9}{|c|}{ Profile 3 - Arenic Haplustalfs } \\
\hline$A(0.00-0.13)$ & 120 & 40 & 840 & 2.38 & 1.34 & 35.3 & 0.11 & 0.33 & 0.44 \\
\hline $\mathrm{AE}(0.13-0.34)$ & 100 & 40 & 860 & 2.60 & 1.46 & 12.1 & 0.19 & 0.25 & 0.44 \\
\hline$E(0.34-0.95)$ & 80 & 20 & 900 & 2.82 & 1.54 & 7.4 & 0.11 & 0.35 & 0.45 \\
\hline \multirow[t]{2}{*}{ Bt $(0.95-1.35+)$} & 320 & 40 & 640 & 2.63 & 1.62 & 11.2 & 0.14 & 0.24 & 0.38 \\
\hline & \multicolumn{9}{|c|}{ Profile 4 - Grossarenic Haplustalfs } \\
\hline$A(0.00-0.13)$ & 80 & 20 & 900 & 2.64 & 1.22 & 11.2 & 0.10 & 0.44 & 0.54 \\
\hline $\mathrm{AE}(0.13-0.40)$ & 80 & 40 & 880 & 2.70 & 1.44 & 9.3 & 0.12 & 0.35 & 0.47 \\
\hline$E(0.40-1.40)$ & 60 & 20 & 920 & 2.70 & 1.59 & 7.4 & 0.08 & 0.33 & 0.41 \\
\hline EB $(1.40-1.86)$ & 80 & 40 & 880 & 2.67 & 1.61 & 7.4 & 0.10 & 0.30 & 0.40 \\
\hline \multirow[t]{2}{*}{ Btg $(1.86-2.50+)$} & 120 & 60 & 820 & 2.67 & 1.75 & 8.4 & 0.05 & 0.30 & 0.34 \\
\hline & \multicolumn{9}{|c|}{ Profile 5 - Aquertic Haplustalfs } \\
\hline$A(0.00-0.22)$ & 140 & 60 & 800 & 2.60 & 0.92 & 31.6 & 0.23 & 0.42 & 0.65 \\
\hline $\mathrm{AE}(0.22-0.53)$ & 100 & 80 & 820 & 2.56 & 1.42 & 14.9 & 0.17 & 0.27 & 0.44 \\
\hline$E(0.53-0.86)$ & 100 & 60 & 840 & 2.60 & 1.63 & 11.2 & 0.10 & 0.27 & 0.37 \\
\hline $\mathrm{Bg}(0.86-1.00)$ & 410 & 80 & 510 & 2.50 & 1.34 & 19.5 & 0.06 & 0.41 & 0.46 \\
\hline$C(1.00-1.40+)$ & 80 & 20 & 900 & 2.67 & 1.59 & 11.2 & 0.09 & 0.32 & 0.40 \\
\hline
\end{tabular}

$\mathrm{PD}=$ particle density; $\mathrm{BD}=$ soil density; $\mathrm{OC}=$ organic carbon; $\mathrm{MaC}=$ macroporosity; $\mathrm{Mic}=$ microporosity; $\mathrm{TP}=$ total porosity.
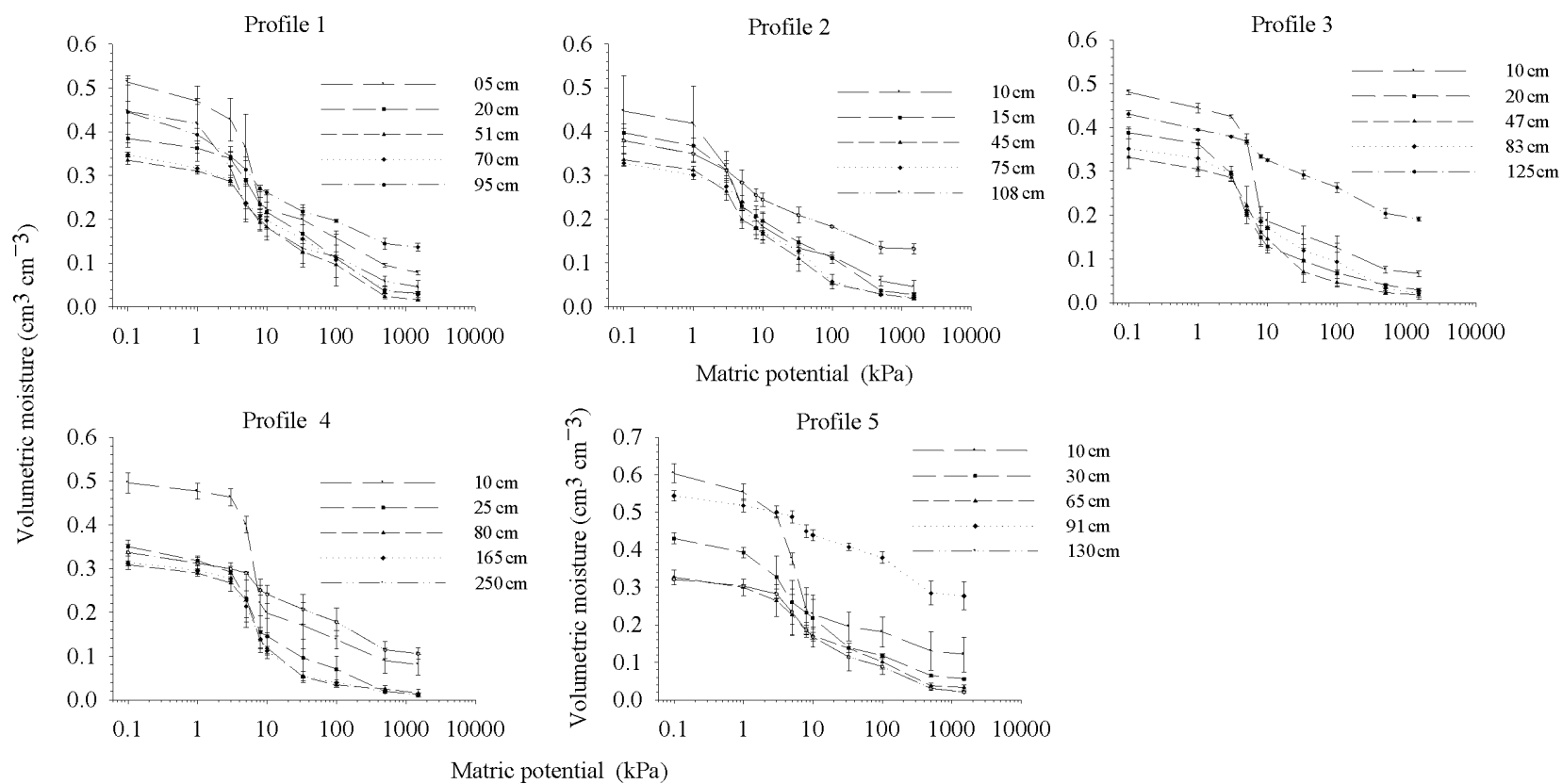

Figure 2 - Water retention curves for profiles of soils of the Caetetus Ecological Station (Gália, SP, Brazil). 

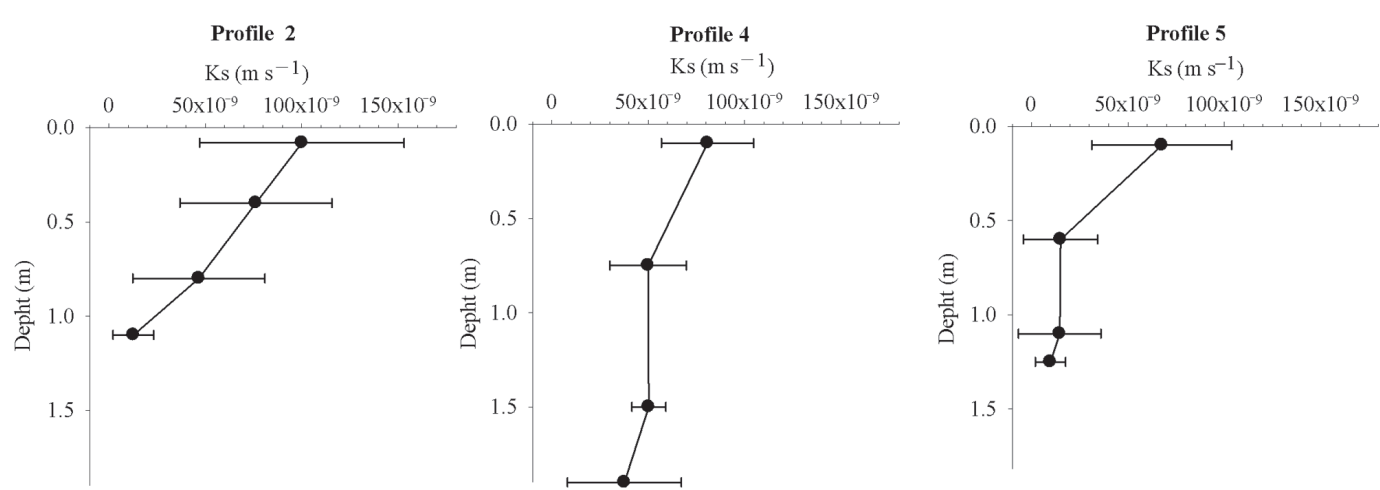

Figure 3 - Saturated hydraulic conductivity (Ks) of the main soil horizons of soils of the Caetetus Ecological Station (Gália, SP, Brazil) (profiles 2 , 4 and 5 , mean and standard deviation).

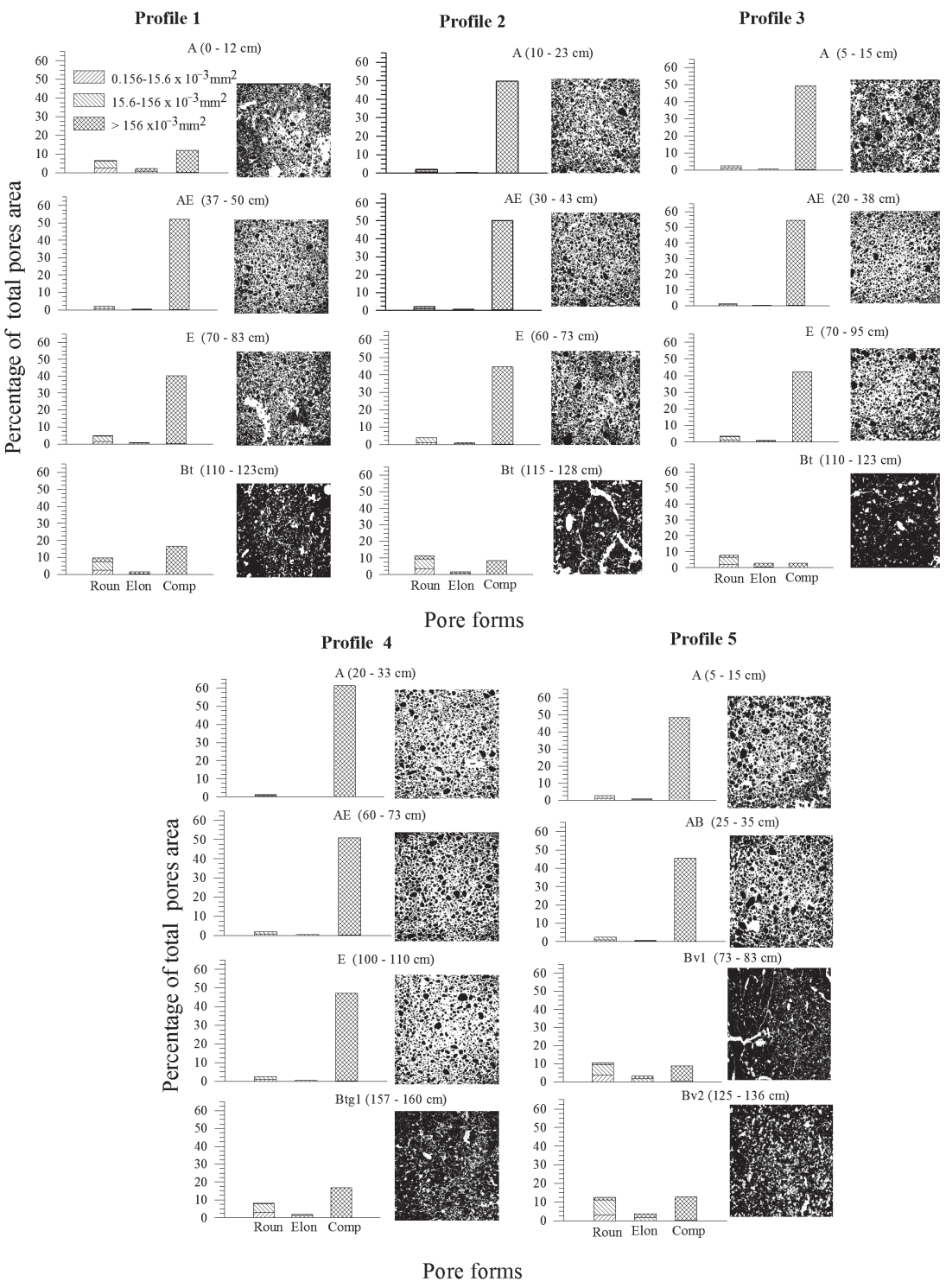

Figure 4 - Rate of the total area occupied by pores, based on the size and shape (R: rounded; E: elongated; I: irregular), obtained from the image analysis, of soils of the Caetetus Ecological Station (Gália, SP, Brazil). 
The differences observed in the behavior of the water retention curve between the sandy $\mathrm{E}$ horizon and the clay B horizon were mainly due to the pore size, type and shape. In the sandy horizons, there was dominance of macropores over micropores, which facilitate the drainage. In the more clay-filled B horizon, a balanced distribution between macropores and micropores exists, which favors water retention. This emphasizes the importance of the B horizon in these soils, which acts as the major water storage medium for plants.

The superficial horizons in all of the transect segments had higher Ks when compared to the sub-superficial horizons (Figure 3). As previously observed for the soil water retention curves, the Ks of these horizons can also be related to the morphological organization, as well as the soil particle size distribution, which provides a high macroporosity in the surface. The macroporosity influences the water flow in the soil, so, high hydraulic conductivity was evidenced in oxic horizons by the high amount of pedotubules (biopores) (Glinski and Lipiec, 1990). These morphological and textural attributes influence the distribution and morphology of the pores, and consequently the hydraulic conductivity. Thus, in the horizons that had less developed aggregates and sandy texture with a dominance of interconnected macropores, the hydraulic conductivity is higher. The $\mathrm{Ks}$ is reduced when the structure is more developed (subangular blocks), with a clayey texture and smaller and less connected pores, as observed in the sub-superficial soils (Figure 3).

Image analysis showed an abrupt transition in the total porosity between the superficial horizons $(\mathrm{A}+$ E) and the sub-superficial horizons (B) (Figure 4). The abrupt modification in the total porosity was mainly due to the changes in the texture and structure of these horizons. These changes, besides changing the total porosity, also modified the morphology of the pores. The dominant porosity in the superficial horizons (A, $\mathrm{E}$ and $\mathrm{EB}$ ) is made up of large irregular pores (drainage pores), while in deeper horizons (Bt, Btg and Bg), a greater balance prevails among the types of pores (Figure 4). These are characterized by a drastic reduction of large irregular pores and an increasing of rounded medium and small pores, with a few elongated pores (retention pores), and was observed between the E and Bt horizons in all profiles. Complex pores still represent almost half of the total porosity of the B horizon, while the other half is represented by the elongated and rounded pores.

The distribution of the pore forms in the B horizon demonstrated good conduction and retention proprieties in this horizon, as also reported by Cooper and VidalTorrado (2005) in Bw horizons, due to the greater development of complex pores in this horizon. The dominance of complex macropores in the $\mathrm{A}$ and $\mathrm{E}$ horizons could explain the typical form of the water retention curve in these horizons, that favor the conduction but not the water retention.

\section{Conclusions}

The toposequence study demonstrated the dominance of well developed and relatively deep soils. The superficial horizons had lower density and greater hydraulic conductivity, porosity and water retention in lower tensions when compared to deeper horizons. The sub-superficial horizons presented greater water retention at higher tensions and lesser hydraulic conductivity due to structure type and greater clay content.

\section{Acknowledgements}

This work was supported/financed by the São Paulo Research Foundation (FAPESP) as part of the BIOTA / FAPESP Program - The Virtual Institute of Biodiversity. The authors also thank André Oppitz Ketzer, Rodrigo Chiara Olsen, Dorival Grisotto and Valter Novais for their aid in the fieldwork.

\section{References}

Blake, G.R.; Hartge, K.H. 1986. Bulk density. p. 363-375. In: Klute. A., ed. Methods of soil analysis, physical and mineralogical methods. ASA, Madison, WI, USA.

Boulet, R.; Chauvel, A.; Humbel, F.X.; Lucas, Y. 1982. Structural analysis and cartography in pedology. I. Considering the twodimensional organization of the soil: toposequence studies and their contributions to the knowledge of soils. Cahiers Orstom Séries Pédologie 19: 309-321 (in French).

Castro, S.S.; Cooper, M.; Santos, M.C.; Vidal Torrado, P. 2003. Soil micromorphology: concepts and applications. Topics in Soil Science 3: 107-164 (in Portuguese).

Chertkov, V.Y. 2004. A physically based model for the water retention curve of clay pastes. Journal of Hydrology 286: 203-226.

Clark, D.B.; Palmer, M.W.; Clark, D.A. 1999. Edaphic factors and the landscape-scale distributions of tropical rain forest trees. Ecology 80: 2662-2675.

Cooper, M.; Vidal-Torrado, P. 2005. Morphological, micromorphological and hydro-physical characterization of soils with a nitic B horizon. Revista Brasileira de Ciência do Solo 29: 581-595 (in Portuguese, with abstract in English).

Dourado Neto, D.; Nielsen, D.R.; Hopmans, J.W.; Reichardt, K.; Bacchi, O.O.S. 2000. Software to model soil water retention curves (SWRC, version 2.00). Scientia Agricola 57: 191-200.

Elrick, D.E.; Reynolds, W.D.; Tan, K.A. 1989. Hydraulic conductivity measurements in the unsatured zone using improved well analyses. Ground Water Monitoring \& Remediation 9: 184-193.

Gee, G.W.; Bauder, J.W. 1986. Particle size analysis. p. 383-411. In: Klute, A., ed. Methods of soil analysis. 2ed. ASA, Madison, WI, USA.

Glinski, J.; Lipiec, J. 1990. Soil physical conditions and plant roots. CRC Press, Boca Raton, FL, USA.

Godefroy, J.; Jacquin, F. 1975. Relation between the structural stability of cultivated soils and organic input in tropical conditions compared with forest soils. Fruits 30: 595-612 (in French). 
Gomes, J.B.V.; Curi, N.; Motta, P.E.F.; Ker, J.C.; Marques, J.J.G.S.M.; Schulze, D.G. 2004. Principal component analysis of physical, chemical, and mineralogical attributes of the cerrado biome soils. Revista Brasileira de Ciência do Solo 28: 137-153 (in Portuguese, with abstract in English).

Guehl, J.M. 1984. Soil water dynamics in humid tropical forests of Guyana. Influence of the soil. Annales des Sciences Forestieres 41: 195-236 (in French).

Klute, A. 1986. Water retention: laboratory methods. p. 635662. In: Klute, A., ed. Methods of soil analysis: physical and mineralogical methods. 2ed. ASA, Madison, WI, USA.

Köppen, W. 1948. Climatology: A Study of the Climates of the Earth. Fondo de Cultura Econômica, Mexico City, México. (in Spanish).

Lemos, R.C.; Santos, R.D. 2002. Field Soil Sampling and Description Manual. 4ed. Brazilian Society of Soil Science, Viçosa, MG, Brazil. (in Portuguese).

Murphy, C.P. 1986. Thin section preparation of soils and sediments.A.B. Academic, Berkhamsted, UK.

Murphy, C.P.; Bullock, P.; Turner, R.H. 1977. The measurement and characterization of voids in soil thin sections by image analysis. I. Principles and techniques. Soil Science 28: 498-508.

Oliveira, R.S.; Bezerra, L.; Davidson, E.A.; Pinto, F.; Klink, C.A.; Nepstad, D.C.; Moreira, A. 2005. Deep root function in soil water dynamics in cerrado savannas of central Brazil. Functional Ecology 19: 574-581.

Quaggio, J.A.; Van Raij, B. 2001. Determination of $\mathrm{pH}$ in calcium chloride and total acidity. p. 173-180. In: Raij, B.V.; Andrade, J.C.; Cantarella, H.; Quaggio, J.A., ed. Chemical analysis for assessing the fertility of tropical soils. IAC, Campinas, SP, Brazil. (in Portuguese).

Quesada, C.A.; Miranda, A.C.; Hodnett, M.G.; Santos, A.J.B.; Miranda, H.S.; Breyer, L.M. 2004. Seasonal and depth variation of soil moisture in a burned open savanna (campo sujo) in central Brazil. Ecological Applications 14: 33-41.
Reynolds, W.D.; Elrick, D.E.; Topp, G.C. 1983. A reexamination of the constant head well permeameter method for measuring saturated hydraulic conductivity above the water table. Soil Science 136: 250-268.

Ringrose-Voase, A.J. 1991. Micromorphology of soil structure: description, quantification, application. Australian Journal of Soil Research 29: 777-813.

Ruggiero, P.G.C.; Batalha, M.A.; Pivello, V.R.; Meirelles, S.T. 2002. Soil-vegetation relationships in cerrado (Brazilian Savanna) and semideciduous forest. Southeastern Brazil. Plant Ecology 160: 1-16.

Sabatier, D.; Grimaldi, M.; Prévost, M.F.; Guillaume, J.; Godron, M.; Dosso, M.; Curmi, P. 1997. The influence of soil cover organization on the floristic and structural heterogeneity of a Guianan rain forest. Plant Ecology 131: 81-108.

Soil Survey Staff. 2010. Keys to Soil Taxonomy. 11ed. USDA/ NRCS, Washington, DC, USA.

Tersteege, H.; Jetten, V.G.; Polak, A.M.; Werger, M.J.A. 1993. Tropical rain-forest types and soil factors in a watershed area in Guyana. Journal of Vegetable Science 4: 705-716.

Topp, G.C.; Zebchuk, W. 1979. The determination of soil water desorption curves for soil cores. Canadian Journal of Soil Science 59: 19-26.

Van Genuchten, M.T. 1980. A closed-form equation for predicting the hydraulic conductivity of unsaturated soils. Soil Science Society of America Journal 44: 892-898.

Vomocil, J.A. 1965. Porosity. p. 299-314. In: Black, C.A., ed. Methods of soil analysis. ASA, Madison, WI, USA.

Wall, A.; Heiskanen, J. 2003. Water-retention characteristics and related physical properties of soil on afforested agricultural land in Finland. Forest Ecology and Management 186: 21-32. 